\title{
Urbanization, Exports and Development of Provinces in Turkey: What Can Government Do?
}

\author{
Hale Akbulut \\ Department of Public Finance, Hacettepe University, Turkey
}

Copyright $(02016$ by authors, all rights reserved. Authors agree that this article remains permanently open access under the terms of the Creative Commons Attribution License 4.0 International License.

\begin{abstract}
Although there seems to be a positive relationship between urbanization levels and development levels in terms of provinces in Turkey, this relationship is not clear. This paper suggests that in the cities with high export volumes, the positive relationship between urbanization and economic development is clearer. The aim of this study may be summarized as an attempt to explain the development in provinces in Turkey in terms of exports and to suggest fiscal policies in order encourage development. For that purpose, the dominant export sectors in provinces are examined, and expectations about their future development are discussed. It is observed that the dominant export sectors are freer from their locations in more developed provinces. In order to promote production and exports in less advantaged regions, government may choose to increase public investment directly or private investment by using different fiscal instruments such as tax exceptions and tax allowances.
\end{abstract}

Keywords Agglomeration Economies, Fiscal Policies, Urbanization

\section{Introduction}

The world is more urban than rural nowadays. Individuals prefer to live in cities or urban areas due to some advantages resulting from high population density and concentration. Nevertheless, urbanization does not always mean development. Therefore, economic policies should be selected carefully in order for urbanization to stimulate economic development.

The aim of development can be summarized as an effort to improve individuals' standard of living. Fundamentally, this aim underlies most economic and social policies. For this reason, development is a vital and heavily studied research area in economics. Because many countries have high levels of income but still have low standards of living, development economists have undertaken the quest to clarify the actual determinants of development. The key determinants are usually considered to be per capita income, capital investments (both human capital and physical capital), factor endowments and so on. Numerous studies have addressed the relationship between these determinants and economic development. I also do not deny the importance of these factors, but this paper focuses on another possible determinant of economic development: some features of the production or export structure of the economy may affect its capability to overcome possible risks.

This paper focuses on the development of provinces in Turkey. In that context, I explore the production or export structure of the provinces and try to evaluate expectations about their development and suggest some public policies. The paper is organized as follows. In section two, I attempt to determine if urbanization really exists both in Turkey and globally. Moreover, the reasons behind urbanization are explored by examining the literature and historical events. In section three, I examine whether urbanization always guarantees development in Turkey and investigate the dynamics of development in provinces in Turkey. Section four presents the conclusions and suggests some fiscal policy recommendations.

\section{Literature}

The world population reached 7.3 billion as of mid- 2015 [1]. A large share of the growth in population has been realized only recently due to high fertility rates. McEvedy, Colin and Jones [2] estimated a population of only 0.9 billion for 1800 .Weeks [3] reports that within 300 years, the number of people mushroomed to more than 6.0 billion after the Industrial Revolution. Rapid population growth, therefore, is a severe problem especially, during the last 300 years.

Another important aspect of population is distribution. The United Nations [4] reports that "60 per cent of the global population lives in Asia (4.4 billion), 16 per cent in Africa (1.2 billion), 10 per cent in Europe ( 738 million), 9 per cent in Latin America and the Caribbean (634 million), and the remaining 5 per cent in Northern America (358 million) and Oceania (39 million)". Thus, the developing world suffers 
from the highest population rates.

Rapid population growth has some serious consequences for poverty, income distribution, demography, education, health and so on, but our concern here is migration. By increasing inequalities, population growth promotes rural-urban migration. Population growth in urban areas is generally higher than the overall population growth. The issue is more severe in the developing world, as expected.

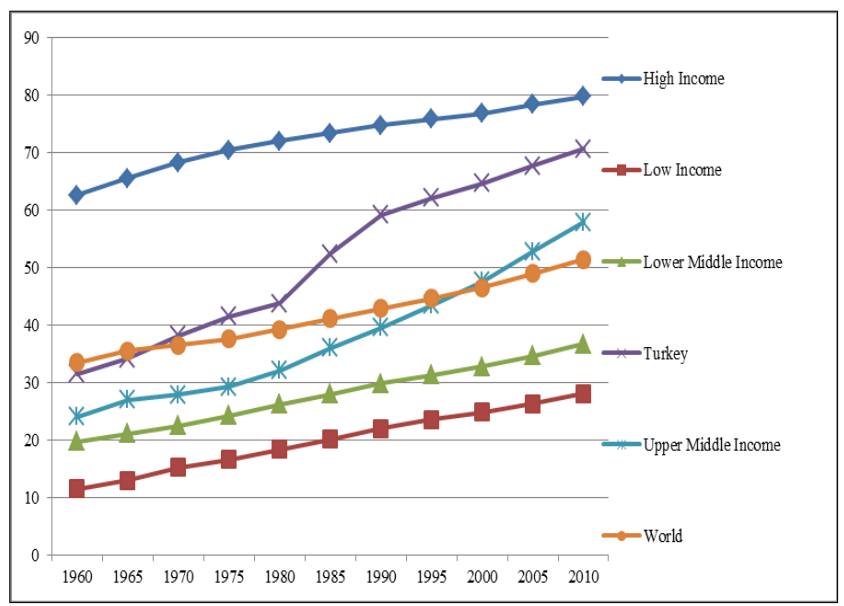

Note: Data is obtained from WB [5]World Development Indicators, Environment: Density \& Urbanization: SP.URB.TOTL.IN.ZS.

Figure 1. Urban Population ${ }^{1}$ (as a percentage of total) for Different Groups of Countries During the Period 1960-2010

The ratio of urban population to overall population is generally increasing worldwide. According to United Nations estimates, the urban population exceeded the rural population in 2008, for the first time in human history [6]. The rate of urban population continues to increase in Turkey, too.

Figure 1 shows the rates of urban population as a percentage of total population for different country groups according to their income levels. One important observation from Figure 1 is that the ranking of country groups according to income levels is similar to their rankings according to urban population rates. Therefore, it is clear that countries with high-income levels are those that also have high urban population rates.

The second important inference from Figure 1 is that urban population rates are generally increasing everywhere regardless of income levels. Thus, increasingly more people prefer to live in cities almost every year.

We can observe positive trends in urban population rates in Figure 1, but it may be useful to investigate the growth rates of the urban population in order to examine if there is a negative rate during some years. For that purpose, Figure 2 shows urban population growth rates (annual per cent) for different group of countries according to their income levels. It can be seen from the figure that the growth rates are always positive for the period 1961-2014 except a negative rate observed in low-income countries in 1975. The cause of this sharp decrease in 1975 is the decrease of the urban population rate in Cambodia. As the government forcibly relocated urban dwellers to rural sites throughout the country $^{2}$ in 1975, an urban population growth of -187.151 per cent was observed in Cambodia. However, ignoring this extreme case, urban population growth is always positive for all country groups from 1961 to date.

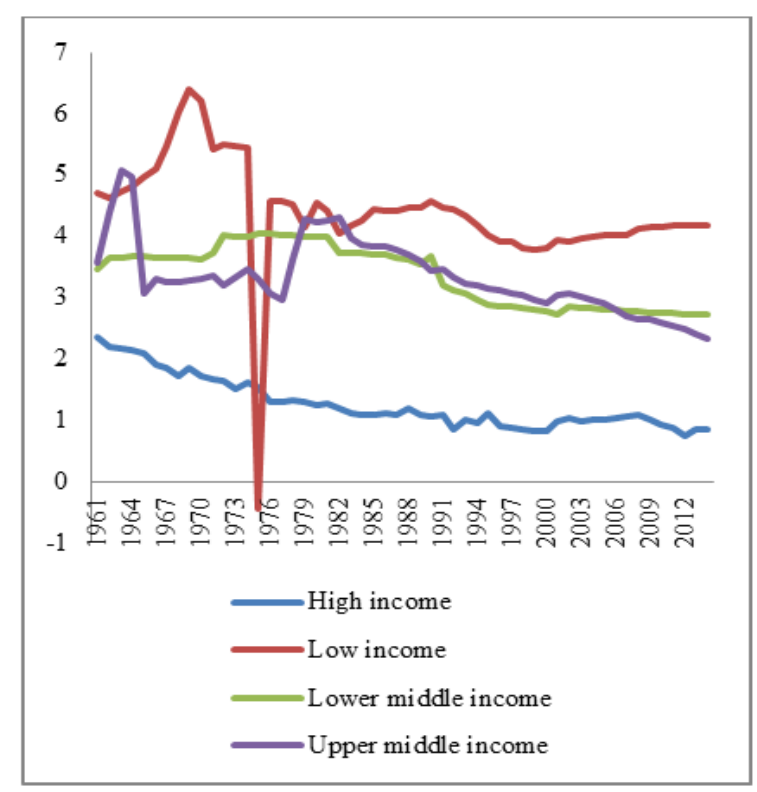

Note: Data is obtained from WB [7],World Development Indicators, Environment: Density \& Urbanization: SP.URB.GROW.

Figure 2. Urban Population Growth (annual per cent) During the Period 1961-2014

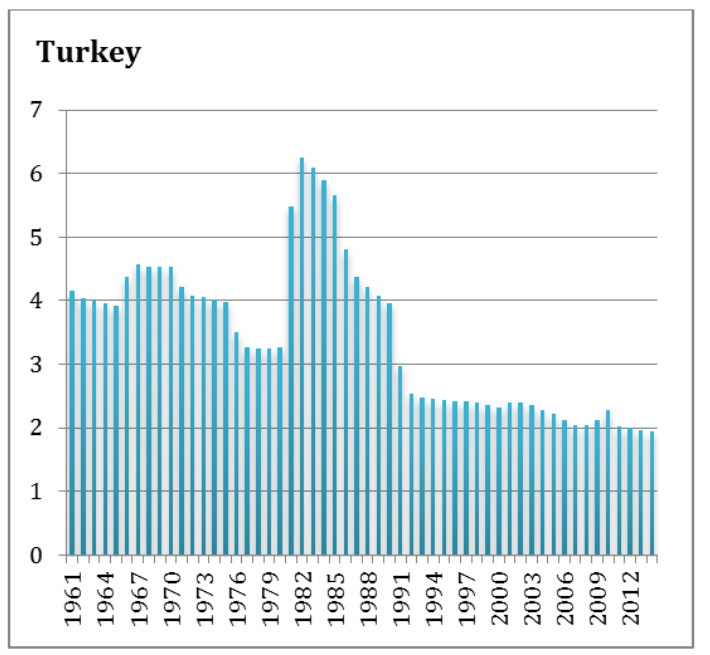

Note: Data is obtained from WB [8], World Development Indicators, Environment: Density \& Urbanization: SP.URB.GROW.

Figure 3. Urban Population Growth in Turkey (annual per cent) During the Period 1961-2014
1 World Bank in World Development Indicators defines urban population as the "people living in urban areas as defined by national statistical offices. It is calculated using World Bank population estimates and urban ratios from the United Nations World Urbanization Prospects".
${ }^{2}$ The causes of the relocation can be found in historical sources under the subject of "Khmer Rouge" for the interested reader. 
Next we look at the urban population growth rates in Turkey. Figure 3 shows the urban population growth rates (annual per cent) during the period 1961-2014 in Turkey. As can be seen from the figure, urban population growth in Turkey has also been positive; people prefer to live in cities in Turkey just as in the rest of the world.

Lastly, we investigate urbanization growth rates in terms of provinces. Figure 4 shows urban population growth rates during the period 2007-2014 for 20 provinces. The rate of population in province and district centers (except from towns and bridges) to total population is used as an indicator of urbanization. The data is obtained from the Turkish Statistical Institute (2015) dataset.

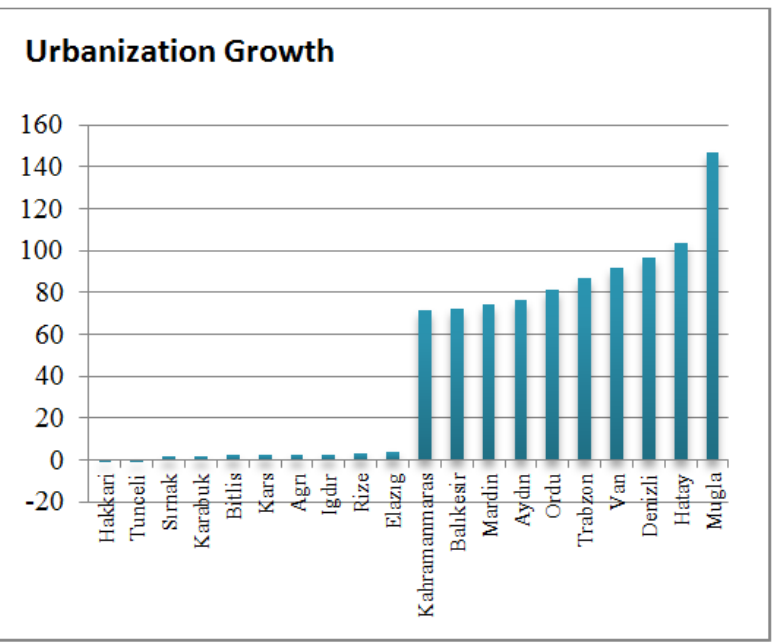

Note: Data is obtained from Turkish Statistical Institute [9], Main Statistics, Population and Demography.

Figure 4. Urban Population Growth in Turkey (per cent) in Some Selected Provinces During the Period 2007-2014

The first 10 provinces in Figure 4 are those that have the lowest rates of urbanization growth: Hakkari, Tunceli, Sırnak, Karabuk, Bitlis, Kars, Agrı, Igdır, Rize and Elazıg. The other 10 provinces are those that have the highest rates of urbanization growth: Kahramanmaras, Balıkesir, Mardin, Aydın, Ordu, Trabzon, Van, Denizli, Hatay and Mugla. As can be seen from the figure, urbanization growth rates are quite different across the provinces. Whereas Mugla has an urbanization growth rate of 146.7 per cent, Hakkari has an urbanization growth rate of -1.2 per cent. Furthermore, urbanization growth rates are not similar even across provinces with similar urbanization rates. For example, Istanbul, with the highest urbanization rate, has an urbanization growth rate of nearly 12.5 per cent; Kocaeli, the third province in Turkey according to urbanization rate, has an urbanization growth rate of nearly 61 per cent during the same period. However, except for two provinces, Hakkari and Tunceli, all the provinces have positive urbanization growth rates during the period 2007-2014. Therefore, we may again conclude that urbanization has increased in almost every province of Turkey. In short, regardless of the income levels and some other factors, urbanization is occurring almost everywhere.
In the previous debates, we concluded that people generally prefer to live in cities in both Turkey and other countries. What, though, are the underlying reasons? And do these reasons change over time? In order to answer these questions, first we must deal with how the locations of cities have been determined throughout history.

The locations of early cities were determined by the ruling class, depending, usually, on safety, defensibility, administrative control and agricultural productivity. However, the factors that determined the location of cities changed, especially after the Industrial Revolution. Meyer [10] points out two kinds of cities arising after the Industrial Revolution: logistic cities and agglomeration cities. With industrialization, firms started to locate their production, transportation and distribution facilities at sites that offered cost advantages. For example, for a firm that is manufacturing cereals, it is rational to locate near agricultural areas in order to decrease transportation costs, or a firm that is manufacturing coal would like to locate near mineral stratums. As more products were produced, logical requirements became increasingly important, and that in turn shaped the location of cities in that period. In other words, the first impact of the Industrial Revolution on the location of cities was the emergence of logistic cities.

On the other hand, it is not so easy to explain why some industries that are free from logistical problems locate near each other. Today, a huge amount of goods and services are comprised of high value products, which usually have no direct dependency on a specific location. Despite the circumstances in question, the manufacturers of these goods and services prefer to locate together and choose to put up with the disadvantages of cities such as pollution and congestion. The reason behind this behavior can be explained by the term "agglomeration economies".

Glaeser [11] defines agglomeration economies as "the benefits that come when firms and people locate near one another together in cities and industrial clusters". There are different types of benefits arising from agglomeration economies, the first of which may be the reduction in costs. Firms benefit from locating in high-density areas as they may easily access low cost inputs, especially labor. They also benefit from the division of labor. The facilities of firms may be provided in a more specialized way, which may also contribute to decreased production costs by increasing efficiency through "learning by doing"[12].

Another important benefit of cities is that they provide the appropriate conditions for the flow of ideas. People living in cities are affected by one another, and ideas flow easily from one person to another. In this way, cities promote the creation of new goods and technologies.

The literature points out three types of spillovers: MAR Spillovers, Porter Spillovers and Jacobs Spillovers. MAR Spillovers are named after the economists Alfred Marshall (1890), Kenneth Arrow (1962), and Paul Romer (1986). They [13-15] pay attention to the firms benefit from locating together in the same industry. A well-known example is Silicon Valley [16]. 
Porter spillovers, named after Michael Porter (1990) like MAR spillovers, are the spillovers within a sector. Porter [17] suggests that local competition instead of local monopolies fosters innovation.

Lastly, Jacobs Spillovers, named after Jane Jacobs (1969) deal with the benefits of firms in different industries locating together, in which case, the flow of ideas of people from different perspectives contributes to the development of new products and production technologies [18].

All the knowledge spillovers arise more easily in cities because high population density facilitates the flow of ideas. In short, the second impact of the Industrial Revolution on the location of cities was the emergence of agglomeration cities. These cities are not dependent on their locations as are logistic cities; instead, they contribute to the development of their locations through increasing productivity as some endogenous growth models [19-21]suggest.

Lastly, individuals may also be attracted to cities because of the broader set of choices. For instance, individuals benefit from locating in high-density areas as they have the choice of more hospitals, schools, cinemas and so on. In short, although the main reasons change over time, economic agents, both producing and consuming, prefer to live as a cluster due to the advantages of such clustering, and urbanization continues to increase generally.

\section{Discussion}

The previous section listed the benefits of cities, but there are also costs to city living that can impact economic development. Congestion, pollution and squatting are the main and well-known costs of cities. In addition, the problems of poverty and income inequality are more severe in urban areas. In this context, urbanization does not always mean economic development.

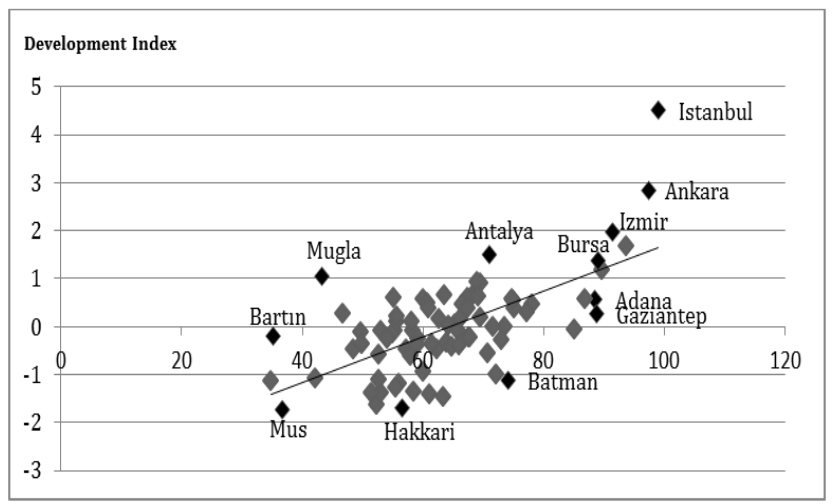

Urbanization Rate

Figure 5. Urbanization and Development of Provinces in Turkey (2011)

Figure 5 shows the relationship between urbanization and development of provinces in Turkey for 2011. I calculated the data for urbanization using data from the Turkish Statistical Institute population database. The ratio of the population in the provinces and district centers to total population is used as an indicator of urbanization. The Socioeconomic Development Index (SEGE) of The Ministry of Development 2011 Report is employed to measure the development of cities. SEGE[22] computed development index for 81 countries by using 61 indicators under 8 main headings: demographic indicators, employment indicators, education indicators, health indicators, competitive and innovative capacity, fiscal indicators, accessibility indicators, and quality of life indicators.

The trend line in Figure 5 indicates a positive relationship between the rate of urbanization and economic development. However, the relationship does not seem to be very clear. In some cities, such as Batman, Diyarbakır, Kilis and Osmaniye, urbanization rates are not as low as for some other cities, but their development levels seem to be low. On the other hand, in other cities such as Canakkale and Mugla, the urbanization rates are not as so high, but their levels of development seem to be satisfactory. This pattern indicates that urbanization does not always mean development. Even so, the figure contains an important finding, although it is difficult to observe. This finding can be more easily seen in Figure 6.

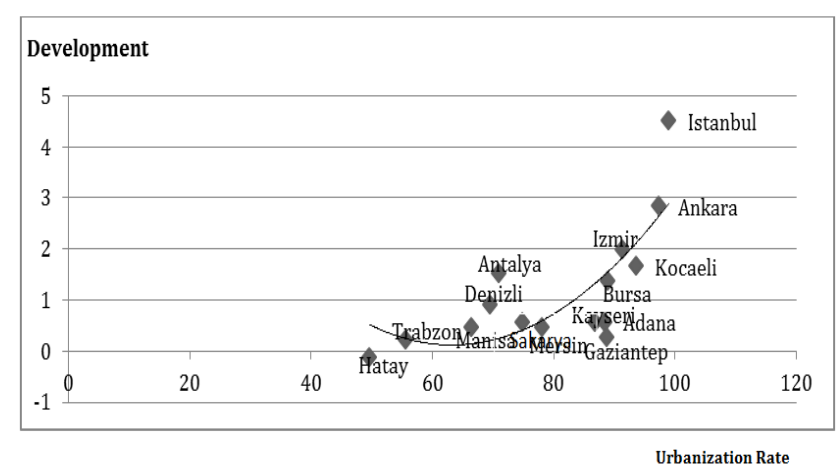

Figure 6. Urbanization and Development of Provinces With Highest Export Volumes in Turkey (2011)

Figure 6 repeats Figure 5 with the 15 cities that had the highest export volumes in 2011. The relationship between urbanization rate and development seems clearer here and the trend seems to be nonlinear. In cities that have high export volumes, urbanization seems to contribute increasingly to economic growth.

Indeed, it is not surprising to observe such a relationship because as cities grow, trading facilities will increase. The increase in the volume of trading facilities combined with preserved property rights encourages individuals to innovate. Taking into account the "homo-economicus" nature of humans, one may suggest that individuals act as economic agents who pursue profit opportunities. This suggestion may also be supported by a well-known historical event: the Industrial Revolution.

I discuss the Industrial Revolution in the second section while explaining its effects on the location of cities, but the city itself also affects the progress of industrialization and development. Thus, the emergence of the Industrial Revolution in Europe may not be a coincidence. 
Undoubtedly, the basics of the Industrial Revolution depend on the progress of rational ideas and science. However, the development of trade markets and profit opportunities may be interpreted as the secret heroes of the Industrial Revolution. In that period, people with no advanced skills or education began to engage in economic activities, and the opportunity to accrue profits motivated them to innovate. Cities were the most efficient places for this dynamic structure to expand because they contained huge trading facilities, provided a large market, and favored the flow of ideas. Therefore, the Industrial Revolution came into existence in the most urbanized areas that had the highest level of trade volume combined with preserved property rights.

The positive effects of trade and export on the economic development may also be attributable to the economic base theory. Although the origin of the theory goes back to mercantilists and physiocrats, the modern concept of the economic base was initially formulated by Werner Sombart [23]. The theory assumes that production is either sold locally or exported to other regions or countries. Therefore, total economic activity can be distinguished as either belonging to the basic or the non-basic sector where the basic sectors produce basically for export market and the latter for the local market. As the exports will generate income for the producers, they will also increase the demand in the local area [24]. Without the producers in basic sector, or if they decline in earning power, the economic health of the community suffers [25]. Thus the export affects the regions' economic development in a positive way ${ }^{3}$.

If we return to the case of Turkey, one may suggest that urbanization alone is not enough for development, and in cities with a high level of exports, urbanization seems more likely to contribute to economic development. Then, can we say something about the development of cities in the future? Now, let us discuss this subject closer.

Meyer [26] draws attention to three types of development cycles: product, technology and relative factor input costs. Most products follow a similar pattern of introduction, growth, maturity and decline. This process is called the product cycle. For example, video cassettes are suggested to be in the period of decline.

The technological cycle is related to production technologies. To use a technology in the most efficient way takes time. On the other hand, existing dominant technology can always be replaced by new technologies.

Changes in input prices are the last risk related to products. Relative factor prices change for different reasons. For instance, raw materials may depreciate, which in turn may lead to an increase in the cost of the material. Similarly, drastic changes in fertility or mortality rates and migration may affect the cost of labor. Some public policies may also create cost differences across regions. For example, different

3 Although I do not descend in this study, the theory of economic base has been refined by some subsequent economists. tax applications or different rates of subsidies in different local units may cause cost differences.

In short, all sectors are faced with some risks depending on their location in each cycle. Meyer [27]draws attention to possibly different outcomes depending on the nature of cities:

"... generating new products or concepts became increasingly important if an economy were to keep pace and develop up to its potential. Because of their access to information and a relatively plentiful supply of diverse and relatively efficient factors of production 'agglomeration cities' seemed particularly attractive for incubation or development of these new products. 'Logistic cities' could also play this role but usually not effectively because of a narrower and less diverse base in supplying activities and information sources. Logistic cities, largely because of their specialization, also seem more vulnerable to adverse turns in product, technological and factor price cycles."

In this context, the nature of a city (logistic or agglomeration) may determine the capability of cities to overcome possible risks. Then, yes, we may speculate about the future of cities depending on their economic features.

Returning to the case of Turkey, we have just observed that in cities with a high level of exports, urbanization seems more likely to contribute to economic development. Let us then first examine the dominant export sectors of cities in order to put forward an idea about the nature of cities. I have divided the cities into three groups. The first group consists of cities that have the largest export volumes (the 15 cities shown in Figure 6) and also have a socioeconomic development index value greater than 1: Istanbul, Ankara, Izmir, Kocaeli, Antalya and Bursa. The second group includes cities again in the first 15 high export volume cities in Figure 6 but also that have an economic development index values less than 1 . This group includes 9 cities that can be listed according to their respective level of development: Denizli, Adana, Kayseri, Sakarya, Manisa, Mersin, Gaziantep, Trabzon and Hatay. The last group includes another 66 cities.

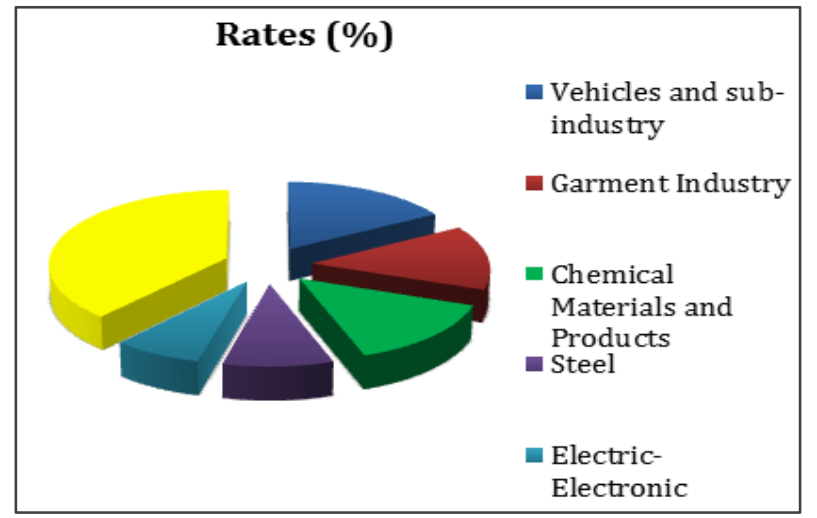

Note: Data is obtained from Turkish Exporters Assembly [28]dataset from the website:

http://www.tim.org.tr/tr/ihracat-ihracat-rakamlari-tablolar.html.

Figure 7. Export Sectors for the First Group of Cities (2013-2014 total) 
Figure 7 shows the dominant export sectors of the first group of cities as a percentage of 2013 and 2014 exports data. Exports data according to sub-sectors is obtained from the Turkish Exporters Assembly.

As previously mentioned, agglomeration cities are more protected from risky periods arising from product and technology cycles and changes in input prices. Not surprisingly, the dominant export sectors of the first group of cities are generally not dependent on their locations, or their exports sectors can benefit more from agglomeration. Considering the high development index value in these cities, the finding is suggested to be as expected.

However, creating an expectation for the rest of the cities (those that have lower development index values) is the main question. Therefore, we again use pie charts in order to observe the dominant export sectors of these cities. Figure 8 shows the dominant export sectors of the second group of cities, which again have a high level of exports but have low development levels. I again employ data for 2013 and 2014 from the Turkish Exporters Assembly.

The first impressive difference in Figure 8 compared to Figure 7 is that the pie segments of the dominant sectors have shrunk. For instance, while the first three sectors in Figure 7 constitute nearly 45 per cent of the total exports, the first three sectors in Figure 8 constitute only 33 per cent of the total exports. One may suggest, therefore, that cities in the second group do not benefit from scale economies and specialization as much as those in the first group.

The second impressive difference is that the Figure 8 pie chart includes two new sectors: 1) cereals, pulse, oil seeds and products and 2) textile and raw materials. These two sectors constitute nearly 19 per cent of total exports and are suggested to be dependent on their location. This situation may cause some pessimistic expectations about the economies of these cities, but other segments of the pie chart should not be ignored.

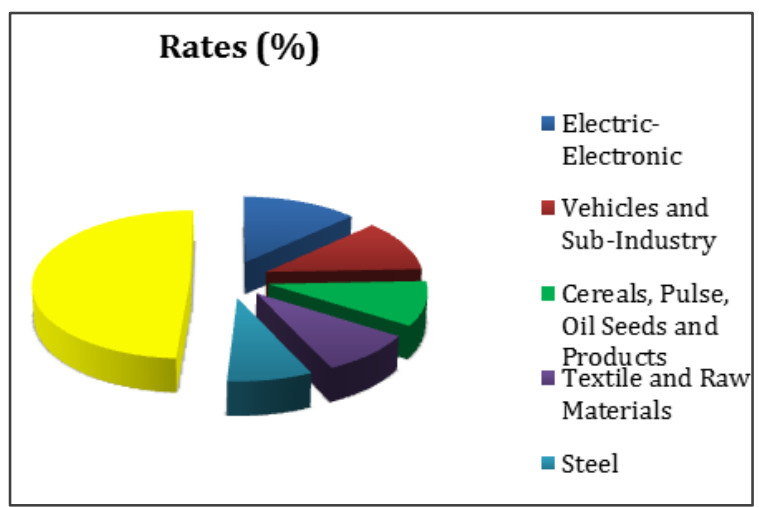

Note: Data is obtained from Turkish Exporters Assembly [29]dataset from the website:

http://www.tim.org.tr/tr/ihracat-ihracat-rakamlari-tablolar.html.

Figure 8. Export Sectors for the Second Group of Cities (2013-2014 total)

The other dominant sectors of the second group of cities are electric-electronic, vehicles and sub-industry and the steel industry. These sectors, which are not heavily dependent on their locations, constitute nearly 32 per cent of the total exports. Therefore, these cities possibly will have better economic performances in the future, as indicated by the development curve shown in Figure 6.

The expectations can be criticized for being quite general. In fact, each city in the second group has its own dynamics and will probably experience different developmental paths. Sakarya, for example, is responsible for nearly 70 per cent of the total exports of the vehicles and sub-industry sector, and Kayseri, Manisa and Denizli together perform nearly 52 per cent of the total exports of the electric- electronic sector. On the other hand, Gaziantep performs nearly 18 per cent of the exports of the cereal, pulse, oil seeds and products sector. Therefore, future expectations for these cities have to be differentiated. However, an examination of the subject for each city requires more effort and is a topic for future studies.

Lastly, the cities that have relatively low export volumes are handled and export performances according to sectors are given, again using a pie chart. Figure 9 shows the dominant export sectors of the third group of cities (residual 66 cities) as a percentage of 2013 and 2014 exports data.

As shown in Figure 9, the first exciting observation is that the magnitudes of the pie segments for the dominant sectors shrink again, and therefore these cities do not benefit from scale economies and specialization as much as the first two groups of cities. These cities, therefore, may benefit from an expansion of the share of their dominant export sectors due to the positive effects of scale economies and specialization.

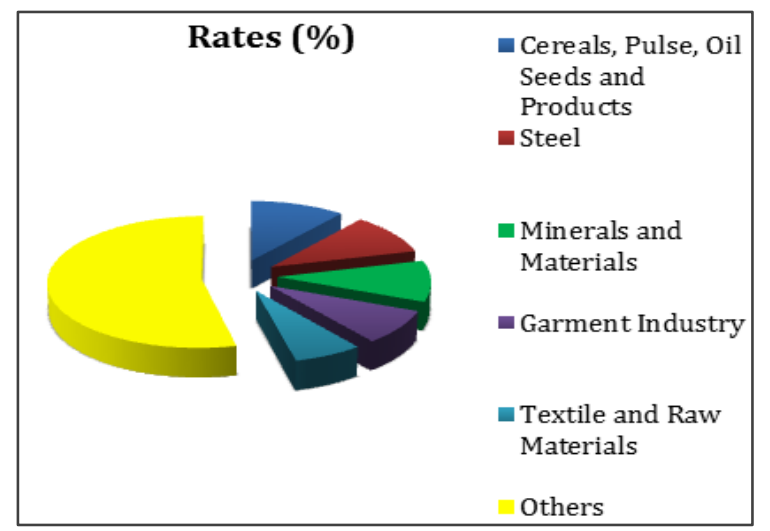

Note: Data is obtained from Turkish Exporters Assembly [30]dataset from the website:

http://www.tim.org.tr/tr/ihracat-ihracat-rakamlari-tablolar.html.

Figure 9. Export Sectors for the Third Group of Cities (2013-2014 total)

The other important observation is that three of the first five dominant export sectors, which are cereal, pulse, oil seeds and products, steel and minerals and materials, can be suggested to be dependent on their locations. Therefore, cities in that group can be argued to be more like localization cities instead of agglomeration cities and therefore may suffer more from possible risks. These cities may have to overcome their dependency on their locations.

\section{Conclusion}

In the previous section, we discussed some possible risks 
that may affect different sectors. We also mentioned that agglomeration cities are more likely to overcome such risks due to knowledge spillovers. However, the formation of agglomeration cities is not so straightforward and easy and sometimes may be impossible without special support. In order, therefore, to decrease the dependency of cities on their locations and increase the ability of both localization and agglomeration cities to overcome possible risks, government may act as a supporter and may implement some fiscal policies.

The first fiscal policy may be to increase public investments in the targeted regions. Figure 10 shows the ratio of public investments for the three groups of cities that are mentioned in the previous sections. The data is the average of the period 2006-2014 and is obtained from The Ministry of Development website.

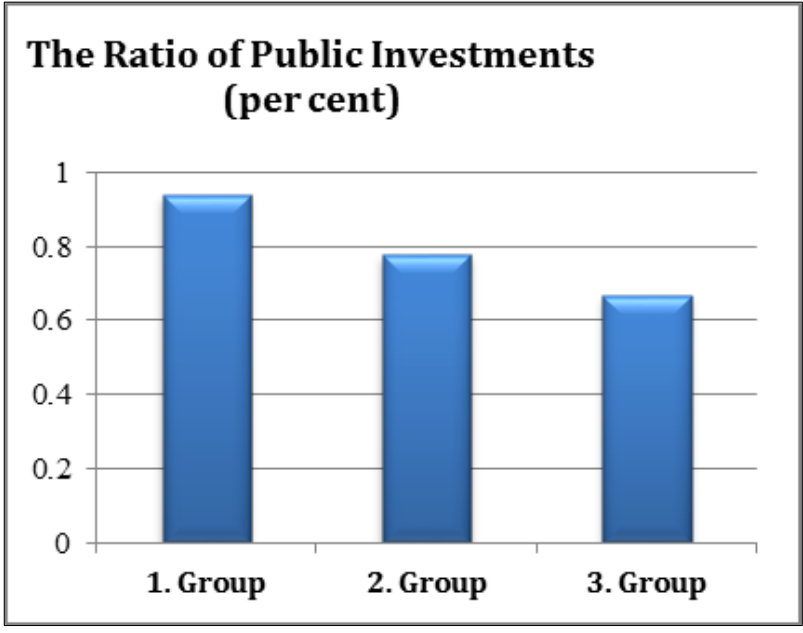

Note: Data is obtained from The Ministry of Development [31]dataset from the website: http://www2.kalkinma.gov.tr/kamuyat/ilozet.html.

Figure 10. The Ratio of Public Investments in the Three Groups of Cities to the Total Public Investments (per cent) (2006-2014 averages)

Remember that the first group of cities includes Ankara, Antalya, Bursa, Istanbul, Izmir and Kocaeli. These cities have the highest rates of export volumes and have development index rates greater than 1 .

These cities receive a larger share of total public investments than the other two groups of cities: the first group of cities receives 0.94 per cent, the second group of cities 0.78 per cent and the third group of cities 0.67 per cent of total public investments ${ }^{4}$.

Similarly, the second group of cities, which are the cities with high export volumes but development index rates less than 1 , receive a larger share of total public investments than the third group of cities. Therefore, by increasing the share of public investments in the second and third groups of cities, government may serve to increase the level of development in these cities.

4The remaining public investments were invested in "various" regions. Detailed information can be found on the website: http://www2.kalkinma.gov.tr/kamuyat/ilozet.html.
The second public policy may be to promote private investment by using different fiscal instruments such as tax exceptions and tax allowances. These instruments are already being used in the Turkish economy. Fundamentally, dealing with less-developed regions is based upon the acceptance of five-year development plans. Five-year development plans have been applied in the Turkish economy since 1963.On 28 February 1968, the "priority regions for development" were first determined in accordance with law No. 202. The first priority regions for development included 22 cities located in the southeast and eastern regions. However, until 1980 the cities in question were considered as a group, and there were no targeted development strategies or incentive systems for them. After 1981, the cities were divided into two groups according to their development priorities.

Today, these cities have been divided into six regions according to their socioeconomic development levels by using the development index of The Ministry of Development (2011), and different investment incentives are being used for these six regions ${ }^{5}$.

The new Investment Incentives System is determined in accordance with law No. 3305, which was introduced on 15 June 2012. The main aims of this system are to direct savings towards high value-added investments, to increase production and employment, to promote large-scaled investments that have large research and development contents, to increase foreign direct investment, to decrease regional discrepancies and to promote agglomeration investments. In order to reach these aims, different fiscal policy instruments such as tax allowances, tax exceptions, tax reductions, interest support and support for employee benefits are being used ${ }^{6 .}$

The third fiscal policy may be to help cities benefit from local tax differences. Low tax rates or some special tax immunities may be employed in order to support the development of targeted regions. However, in Turkey, taxation authority is under the purview of the legislative body, and municipal administrations have only collecting power. So by improving fiscal localization, efficient development policies may be applied in terms of provinces.

The last fiscal policy may be to create extra budgetary funds. These funds can be used easily and quickly without bureaucratic limitations. However, taking into account the distortionary role of these funds on the transparency of the budget, this policy may not be preferable.

To sum up, taking into account the supportive role of exports on the development of provinces, government may benefit from a variety of fiscal policy instruments, each of which has its own advantages and disadvantages. On the other hand, considering that each city has different strengths and weaknesses, the requirement of more specific development strategies should not be ignored.

5Appendix 1 shows the six regions and the related cities according to their socioeconomic development levels.

6Detailed information can be found in the" Investment Incentives System

Annual Evaluation Reports" on the website of The Ministry of Economy. 


\section{Appendix . The Six Regions According to Their Socioeconomic Development}

\begin{tabular}{|c|c|c|c|c|c|}
\hline 1. Region & 2. Region & 3. Region & 4. Region & 5. Region & 6. Region \\
\hline Ankara & Adana & Balıkesir & Afyonkarahisar & Adiyaman & Agr1 \\
\hline Antalya & Aydın & Bilecik & Amasya & Aksaray & Ardahan \\
\hline Bursa & Bolu & Burdur & Artvin & Bayburt & Batman \\
\hline Eskisehir & Canakkale & Gaziantep & Bartın & Çankırı & Bingol \\
\hline Istanbul & Denizli & Karabuk & Çorum & Erzurum & Bitlis \\
\hline Izmir & Edirne & Karaman & Düzce & Giresun & Diyarbakır \\
\hline Kocaeli & Isparta & Manisa & Elazığ & Gumushane & Hakkari \\
\hline \multirow[t]{10}{*}{ Mugla } & Kayseri & Mersin & Erzincan & Kahramanmaras & Igdır \\
\hline & Kırklareli & Samsun & Hatay & Kilis & Kars \\
\hline & Konya & Trabzon & Kastamonu & Nigde & Mardin \\
\hline & Sakarya & Usak & Kırıkkale & Ordu & Mus \\
\hline & Tekirdag & Zonguldak & Kırşehir & Osmaniye & Siirt \\
\hline & Yalova & & Kutahya & Sinop & Sanliurfa \\
\hline & & & Malatya & Tokat & Sirnak \\
\hline & & & Nevsehir & Tunceli & Van \\
\hline & & & Rize & Yozgat & \\
\hline & & & Sivas & & \\
\hline
\end{tabular}

Note: The table is based on The Ministry of Development (2011) SEGE Report Incentive System Map.

[13] A. Marshall, Principles of Economics, Macmillan, London, 1890.

\section{REFERENCES}

[1] United Nations. World Population Prospects 2015 Revision, 2015.

[2] C. McEvedy, R. M. Jones. Atlas of World Population History, Penguin, New York, 1978.

[3] J. R. Weeks.. Population: An Introduction to Concepts and Issues, Wadsworth Publishing Co Belmont, CA, 2008.

[4] United Nations. World Population Prospects 2015 Revision, 2015.

[5] World Bank. World Development Indicators, Environment: Density \& Urbanization: SP.URB.TOTL.IN.ZS., 2015a.

[6] M. P. Todaro, S. C. Smith. Economic Development, Addison-Wesley, Boston, 2012.

[7] World Bank. World Development Indicators, Environment: Density \& Urbanization: SP.URB.GROW., 2015b.

[8] World Bank. World Development Indicators, Environment: Density \& Urbanization: SP.URB.GROW., 2015 b.

[9] Turkish Statistical Institute. Main Statistics, Population and Demography, 2015.

[10] J. R. Meyer. The Role of Industrial and Post-Industrial Cities in Economic Development, Working Paper (00-1), Joint Center for Housing Studies, Harvard University, 2000.

[11] E. L. Glaeser. Agglomeration Economics, Edited by. Edward L. Glaeser, University of Chicago Press, Chicago, 2010.

[12] K. J. Arrow. The economic implications of learning by doing, The Review of Economic Studies, Vol. 29, No. 3, 155-73, 1962.

[14] K. J. Arrow. The economic implications of learning by doing, The Review of Economic Studies, Vol. 29, No. 3, 155-73, 1962.

[15] P. M. Romer. Increasing returns and long-run growth, The Journal of Political Economy, Vol.94,No. 5, 1002-37, 1986.

[16] B. W. Arthur. Silicon Valley Locational Clusters: When Do Increasing Returns Imply Monopoly?, Working Paper (007), Sante Fe Ins, Sante Fe, 1989.

[17] M. E. Porter, The Competitive Advantage of Nations, Free Press, New York, 1990.

[18] J. Jacobs, The Economy of Cities, Vintage, New York, 1969.

[19] P. M. Romer. Increasing returns and long-run growth, The Journal of Political Economy, Vol.94,No. 5, 1002-37, 1986.

[20] R. E. Lucas. On the mechanics of economic development, Journal of Monetary Economics, Vol.22, No. 1988, 3-42, 1988.

[21] S. Rebelo. Long-run policy analysis and long-run growth, Journal of Political Economy, Vol. 99, No. 3, 500-21, 1991.

[22] The Ministry of Development. SEGE Report. online available from: http://www.ab.gov.tr/files/ardb/evt/2_turkiye_ab_ilisk ileri/2_2_adaylik_sureci/2_2_8_diger/tckb_sege_2013.pdf, 2011.

[23] R. Noel., R. Arnason. and W. E. Schrank. The identification of economic base industries, with an application to the Newfoundland fishing industry, Land Economics, Vol. 85, No. 4, 675-691, 2009.

[24] R. B. Andrews. Mechanics of the urban economic base: historical development of the base concept, Land Economics, Vol. 29, No. 2, 161-167, 1953. 
[25] P. Thulin. Local Multiplier and Economic Base Analysis, Working Paper (29), Swedish Entrepreneurship Forum, 2014.

[26] J. R. Meyer. The Role of Industrial and Post-Industrial Cities in Economic Development, Working Paper (00-1),Joint Center for Housing Studies, Harvard University, 2000.

[27] J. R. Meyer. The Role of Industrial and Post-Industrial Cities in Economic Development, Working Paper (00-1),Joint Center for Housing Studies, Harvard University, 2000.
[28] Turkish Exporters Assembly. online available from:http://www.tim.org.tr/tr/ihracat-ihracat-rakamlari-tablo lar.html, 2015.

[29] Turkish Exporters Assembly. online available from:http://www.tim.org.tr/tr/ihracat-ihracat-rakamlari-tablo lar.html, 2015.

[30] Turkish Exporters Assembly. online available from:http://www.tim.org.tr/tr/ihracat-ihracat-rakamlari-tablo lar.html, 2015.

[31] The Ministry of Development. online available from: http://www2.kalkinma.gov.tr/kamuyat/ilozet.html, 2015. 